\title{
REIS NAAR HET MEERGEBIED VAN DEN KAPOEAS IN BORNEO'S WESTERAFDEELING
}

\author{
DOOR
}

L. W. C. GERLACH.

Den 13den Maart 1881 vertrokken wij des middags met den stoomer der Gouvernements-marine, de Boni, naar Sintang, waar wij den 17 den Maart des morgens om zeven uur aankwamen. Men stoomt daartoe aauhoudend den Kapoeas op, eene kolossaal groote rivier met een énorm stroomgebied. Wij hebben namelijk met de Boni, een raderstoomschip bewapend met zeven stukken, dat een diepgang heeft van ruim vịf voet, de rivier opgestoomd tot Sibauw en hadden toen 140 geographische mijlen afgelegd met inbegrip der vele en dikwijls zeer groote kronkelingen. $\mathrm{Zij}$ wordt aan den oorsprong gevormd door eene menigte kleine riviertjes en beekjes, die alle of althans voor het grootste gedeelte hun oorsprong hebben in het Centraal-Gebergte, dat met eenige vertakkingen Borneo van het zuidwesten naar het noordoosten doorsnijdt en niet zeer hoog, hier en daar zelfs eenvoudig een hoogland is; op verschillende plaatsen heeft het andere namen, meestal naar den een of anderen uitstekenden top. De rivier lonpt van het noordoosten naar het zuidwesten en valt met zeven mondingen in zee. Evenals bij vele der groote rivieren van Indië hebben zich echter vóor de mondingen zandbanken gevormd, zoodat het voor eeuigszins groote schepen moeielijk is binnen te komen, en daartoe steeds op den vloed gewacht moet worden; de meeste dezer monden kan men zelfs alleen binnenkomen met kleine prauwen. Natuurlijk is dit een van de voornaamste oorzaken van den weinigen handel en nijverheid en dus van de zeer geringe productiviteit van dit door de natuur zoo rijk bedeelde gewest.

De breedte van den Kapoeas is zeer groot, op vele plaatsen meer dan 800 meter. Het water is bruin gekleurd, doch zeer goed drinkbaar, althans tot op een uur of vijf van de monding, want tot zoover is eb en vloed merkbaar en het water brak.

4e Volgr. V. 
Als oorzaak van de bruine kleur van het water wordt opgegeveı, dat het regenwater, waardoor de stroom hoofdzakelijk gevoed wordt, sijpelt door de sedert eeuwen vele voeten hoog geworden laag bladeren in de zeer boschrijke streken, waardoor de rivier met hare takken loopt. Ik kan mij hiermede wel vereenigen, doch schrijf het dan vooral toe aan het vele zoogenaamde ijzerhout, dat men in die streken vindt, en dat de eigenschap heeft, zwart te worden, wanneer het aan de lucht wordt blootgesteld. Zeker is het, dat het water, hoe lager de waterstand is, des te donkerder gekleurd is; op sommige plaatsen is het zelfs zoo donker, dat het, nadat het door een leksteen gezuiverd is, toch nog de kleur behoudt van rum met water; overigens is het helder en volkomen goed van smak, voor de gezondheid is het dan ook volstrekt niet schadelijk; integendeel er zijn zeer bevoegde personen, die zelfs beweren, dat het zeer gezond is, dit water te drinken. Op de SiakRivier, die op de Oostkust van Sumatra tegenover het eiland Bangkalis hare uitwatering heeft, heb ik hetzelfde waargenomen. Men schreef het daar toe aan de omstandigheid, dat het stroomgebied dezer rivier voor een zeer groot gedeelte liep door steen. koolhoudende streken (het Ombiliëu-kolenveld met zijne voortzettingen); ook eenige inlandsche hoofden (Maleiers), die ik er toen naar vroeg, waren deze meening toegedaan. Ook hier zoude dit wei een van de oorzaken kunnen wezen, zoo niet de oorzaak, want geheel Borneo bevat in meerdere of mindere mate steenkool. Ik vroeg het hier ook aan enkele hoofden, doch zij antwoordden eenvoudig, dat zij het niet wisten; waarschijnlijk hadden zij er nooit over nagedacht, hetgeen ook wel zoo gemakkelijk is.

Verscheidene der zijtakken van den Kapoeas kunnen ook tot de zeer groote rivieren gerekend worden, zooals de Landak, waarin dicht bij de monding de Embawang valt, de Tajan, de Meliauw, de Sangauw, de Sekadauw, de Spauk, de Tempoenah, de Melawi, de Kantauw, de Tawang en de Boenoet. Vele dezer rivieren dragen verschillende benamingen naar gelang van de streek, waardoor zij loopen, hetgeen bij aardrijkskundige nasporingen dikwijls zeer lastig is; men kan de meeste tot 10 à 12 dagen opstoomen en dan nog eenige dagen veıder oproeien.

De oevers zijn over het algemeen zeer laag, zoodat op vele plaatsen het land zelfs bij zeer gewonen waterstand tot op eenigen afstand overstroomd wordt. Dit schijnt echter volstrekt niet te hinderen aan den prachtigen en weelderigen plantengroei, die 
men overal langs de rivier aantreft. Het is werkelijk een schoon tafereel, die aaneenschakeling van nu eens kolossaal hooge en dan weder lage boomen, met hunne roode, paarse, gele en witte bloemen, die bij sommige in groote trossen neerhangen. De stammen zijn dikwijls nog overdekt met prachtig bloeiende orchideeën, terwijl er zich verschillende soorten van lianen, waaronder van reusachtige afmetingen, zoo fantastisch mogelijk doorheenslingeren. Ook de groote verscheidenheid in vorm der bladeren met hunne prachtige schakeering, van af het lichte Mei-groen tot het bruine October-rood, streelt het oog. Want ook hier zooals in Europa verwisselen de boomen van blad, sommige zelfs tweemaal in het jaar, andere eens per jaar, en weder andere doon er langer over; doch het trekt hier minder de aandacht, omdat telkens voor een afgevallen blad een nieuw uitspruit, terwijl in Europa de bladeren binnen eenige dagen afvallen, om zich later bijna weder gelijktijdig te vertoonen. Hier is altijd aan denzelfden boom het eene blad veel ouder dan het andere, vanwaar dan ook die eeuwigdurende kleurschakeering tusschen lichtgroen en bruinrood. Doch hoe verrukkelijk schoon dit schouwspel ook is, toch wordt het wel wat eentoonig, wanneer men daar zoo dagen achtereen langs stoomt, want maar zelden vertoonen zich kampongs of aan den oever staande huizen.

De voornaamste kampongs zijn: Telok Kompei, Soeka Lanting, Djamboe, Tajan, Meliauw, Sangauw, Sekadauw, Sintang, Silat, Smitauw, Soewahied, Salimbauw, Piassa, Djonkong en Boenoet. Te Tajan en Sangauw is een Kontroleur en te Sintang een Assistent-Resident, met een garnizoen van 1 kompagnie infanterie, één officier van gezondheid en een klein detachement vesting-artilierie. Verder is er nog een militaire post te Nanga Pinoh, een dag stoomens de Melawi-Rivier op; het garnizoen bestaat er uit een klein detachement infanterie met een luitenant en ook daar bevindt zich een Kontroleur. Dan heeft men nog een militaire post in de streek der Batang Loepar Dajaks, dicht op de grens van Serawak, namelijk Nanga Badauw, waar een detachement infanterie met twee officieren en een officier van gezondheid ligt, terwijl de Kontroleur van de Boven-Kapoeas te Smitauw verblijf houdt.

De bevolking dier kampongs bestaat voor het grootste gedeelte, zoo niet geheel uit Maleiers en Boegineezen, die zich hier langzamerhand gevestigd hebben, om handel te drijven; 
ook natuurlijk uit eenige Chineezen, want deze vindt men over den geheelen Archipel verspreid tot in het diepste binnenland. Vroeger woonden ook veel Dajaks aan de rivier; doch deze werden telkens door de bemanning der opvarende prauwen en bandongs zoodanig mishandeld, daar men hun eenvoudig afnam, wat men noodig had, meestal zonder betaling, dat zij langzamerhand hunne woningen verlaten hebben en zich meer in het binnenland vestigden. Hier en daar vindt men nog wel langs de oevers verlaten huizen in meer of minder vervallen toestand, hetgeen een bewijs is, dat daar vroeger Dajaks gewoond hebben, die daar ladangs hadden outgonnen.

1)e Dajaks in deze streken verbouwen namelijk de rijst op ladangs; de sawah-bouw is hier geheel onbekend. Wanneer zij ergens eene plaats vinden, die wat hoog gelegen is en hun geschikt voorkomt, slaan zij zich daar neder; het daarop groeiende hout wordt omgekapt en verbrand, men gaat in het bosch en velt daar de noodige materialen voor het bouwen van hutten. Daarna werkt men den grond wat om met primitieve patjols en pikken; de padi wordt gezaaid; op eenvoudige wijze wordt het bezaaide land ompaggerd, om het indringen van herten en wilde zwijnen te beletten, die hier overai in vrij groote hoeveelheid gevonden worden; dan wacht men geduldig den oogst af. Blijkt het na den eersten oogst, dat de grond niet zoo goed is, als men aanvankelıjk dacint, dan breekt men eenvoudig weder op en zoekt eene andere plaats; anders blyft men er, totdat de bodem uitgeput raakt, want tot verbetering van den grond doet men natuurlijk niets. Men zaait en oogst alleen, en zelfs het onkruid laat men meestal naar welgevallen groeien. Bij het verhuizen laat men de woningen eenvoudig staan; op de nieuwe woonplaats bouwt men weder nieuwe, daar de materialen steeds bij de hand en maar voor het kappen zijn.

Het hoofdroedsel der Dajaks is rijst, die hier bijzonder goed slaagt; de Melawi-rijst, welke verbouwd wordt in het zuidoostelijk gedeelte van Sintang, waardoor de Melawi-Rivier loopt, is zelfs zeer goed; zij heeft alleen het gebrek, niet lang bewaard te kumnen worden, daar er spoedig veel stof en ongedierte in komen. De productie is voldoende voor de consumptie; er wordt weinig rijst uitgevoerd en dan nog maar in kleine hoeveelheden, doch zelden behoeft er rijst te worden ingevoerd. Veel anders verbouwen zy niet als alleen wat djagong, ketella, lombok, een soort van komkommers, die zeer groot zijn en een 
zoeten smaak hebben, eindelijk katjang en eenige bladgroenten, waarmede zij hanne rijst eten.

Veel levendigheid van dieren zagen wij aan de oevers ook al niet, alleen nu en dan enkele vogels, voornamelijk een kleine soort van vischvalk, bruin met witten kop, en dan den bangan, dien men in alle lage streken van den Indischen Archipel vindt; hij is iets kleiner, maar heeft overigens veel overeenkomst met den Hollandschen ooievaar; er zijn hier twee soorten, de witte met oranje vederen aan hals en borst en de grijze, die echter veel zeldzamer is. Ook zagen wij van tijd tot tijd eenige apen; deze dieren, nieuwsgierig als zij zịnn, kwamen op het geluid af, dat de raderen van onzen stoomer in het water maakten, in kleine troepjes tot in de buitenste aan den oever groeiende boomen, om te kijken, wat er toch eigentlijk aan de hand was. Velen namen onmiddellijk de vlucht, wanneer zij dat groote zwarte monster zagen, dat daar zoo statig door het water ging, doch andere, die wat meer brutaal of nieuwsgierig waren, bleven het met aandacht nastaren; zoodra echter de rook uit den schoorsteen naar hunne zijde sloeg, maakten zij als de wind, dat zij wegkwamen; die kolendamp schijutdus ook zelfs voor wilde apen niet aangenaam te wezen. Er zijn hier twee soorten, namelijk de grijze en zwarte aap, in groote hoeveelheid; ook is het hier het land van den orang-oetan, doch dien zagen wij natuurlijk niet; daar hij zich veel dieper in het bosch ophoudt. In de verschillende zijriviertjes en kreken huist eene menigte krokodillen; het was echter hoog water, zoodat wij er niet een gezieu hebben, zij trekken dan dieper het land in.

Te Soengei Aja, drie dagen stoomens van Pontianak, waar wij een steenkolen-depôt hebben, en de Boni zijn kolenvoorraad moest bijladen, gingen wij aan land. Ongeveer een half uur landwaarts liggen goudmijnen, die door Chineezen geëxploiteerd worden. De regeling daarvan is zoo wat de volgende: het Gouvernement verpacht de mijnen tegen een jaarlijksche pachtsom, dan vormt zich een kongsi van verschillende Chineezen, en worden andere Chineezen aangeworven voor de exploitatie. Voor deze moet betaald worden aan den pachter $f 1$ 's maands, een soort van hoofdgeld, waarvan alleen de kok is vrijgesteld. Verder betaalt de kongsi aan de mijnwerkers een zeker werkloon 's maands en voorziet hen tevens van levensmiddelen; de hoeveelheid en soort der voeding, waarvan het hoofdbestanddeel rijst is, wordt vooraf bij contract vastgesteld. 
Het goudzoeken geschiedt door het uitgraven der goud houdende aarde; deze wordt in lange houten goten geworpen, waardoor men water laat loopen, zoodat het zand wegvloeit en het metaal bezinkt. Ieder halfjaar wordt het goud verzameld en is dan het eigendom der kongsi, die het zoo spoedig mogelijk verkoopt. Slechts tweemaal in het jaar bij de algemeene inzameling mag goud verkocht worden, tusschentijds niet. Het goud, dat gevonden wordt, is stofgoud. De waarde van de thail bedraagt van 75 tot 85 gulden; meestal wordt het in den handel gebracht in kleine staafjes van één thail, somtijds ook wel als stofgoud.

De opbrengst is alleen het eigendom van de kongsi, de mijnwerkers ontvangen niets dan hun maandelijksch werkloon en den kost; sommmige van hen eshter, die wat geld hebben, steken dit ook in de kongsi en deelen dan natuurlijk in de winsten en verliezen. Er waren daar een vijftig-tal Chineezen aan het werk; door de ambtenaren werd mij medegedeeld, dat er jaarlijks zooveel goud gevonden wordt, dat kongsi en mijnwerkers ordentelijk hun brood hebben, zonder meer; de productie is dus niet groot. $\mathrm{Zij}$ zijn echter zeer geheimzinnig met het opgeven van de hoeveelheid gevonden goud en van hunne verdiensten; ik vroeg er eenigen naar, maar zij gaven zeer ontwijkende antwoorden.

Ik vond het aardig, aan de mijn zelf eene kleine hoeveelheid goud te koopen, doch dit kostte heel wat moeite. In het zoogenaamde kongsi-huis van de mijn was een lid der kongsi, een oude Chinees met nog eenige andere Chineezen, die ons een kopje kokend heete en zeer sterke thee liet drinken, want evenals bij de Geldersche boeren de koffiekan, is bij de Chineezen de theepot steeds in functie bij elk bezoek, onverschillig hoeveel maal en op welk uur van den dag of nacht. $\mathrm{Ik}$ begon met te vragen, iets van het gevonden goud te mogen zien, doch zij verklaarden mij, niets te hebben, want het was nog niet de tijd van de halfjaarlijksche inzameling. Na lang praten ging echter de oude heer naar een grooten koffer; die met twee stevige sloten dicht gemaakt was, en haalde daaruit een heel klein pakje papier in den vorm van een apothekerspoeder, zorgvuldig met een draadje omwikkeld; heel voorzichtig werden de vele vouwen losgemaakt, en toen kwam er alweer een papiertje, waarin zich een hoeveelheid stofgoud bevond, zooveel als op de punt van een mes kan liggen. Ik vroeg hem toen, dit aan 
mij te verkoopen, doch daar kon niets van komen, want zeide de oude heer, dit mocht niet, en wilde hij dus ook niet doen; hoe wij ook praatten, het hielp niets, en intusschen was hij druk bezig, om het met de meest mogelijke voorzichtigheid weder in te pakken en het draadje er om heen te wikkelen. Zeker zoude ik het dan ook niet gekregen hebben, wanneer wij den pastoor Staal niet bij ons gehad hadden.

Van dezen geestelijke is de stanlplaats Banka, doch hij gaat tweemaal 's jaars naar de groote plaatsen van Borneo's Westkust, om dienst te doen; hij makte de reis met mij tot Sintang en was ook mede naar de mịnen gegaan. Te Banka aanhoudend onder de Chineesshe tinmijnwerkers zijnde, warrbij zich een kleine Katholieke gemeente gevormd heeft, is hị zich gaan toeleggen op de Chineesche taal en heeft het daarin reeds zoover gebracht, dat hij zonder veel moeite een Chineesch gesprek kan voeren; zelfs preekt hij in zijne gemeente in de Chineesche taal, hetgeen het beste middel is, om onder onze gestaarte broeders proselieten te maken. De heer Staal begon den ouden heer aan het verstand te brengen, dat ik een hooggeplaatst persoon van de Kompanjie was, dat ik gaarne wat goud van de mijn wilde medenemen, en dat hij dus dat kleine beetje nu maar aan mij moest verkoopen, daar hij het geld immers in de kongsi-kas konde bewaren en het dan kon be:chouwen, alsof hij het verkocht had bịj de eerstvolgende halfjaarlijksche verkooping. Eindelijk liet de Chineesche behoudsman zich overhalẹn; het pakje werd weder zorgvuldig losgemaakt, de inhoud zeer nauwkeurig op een klein schaaltje gewogen en met het Chineesche telbord werd dadelijk uitgerekend, dat ik daarvoor moest betalen 1 gulden, 3 kwartjes en 9 duiten; daarna werd mij het pakje door den grijsaard overgereikt, maar met een diepen zucht. Om zijn geweten wat te verlichten, betaalde ik $f 2$, daar ik geen klein geld bij mij had, waarvoor de oude man zeer gevoelig scheen; ik gaf hem bovendien een dikke Manilla-sigaar, die hij onmiddellijk met heel veel gratie opstak.

Den volgenden dag, 17 deu Maart, kwamen wij te Sintang, waar wij twee dagen moesten blijven voor het laden van goederen en kolen en voor het schoonmaken der machine.

Den 20sten stoomden wij den Kapoeas weder op naar Poeloe Madjang, gelegen in de zoo bekende, ik zoude haast zeggen, o'n hunne natuurgesteldheid vermaarde meren. De As- 
sistent-Resident van Sintang ging mede tot het afdoen van bestuurszaken in den Boven-Kapoeas, en te Smitauw zouden wij den Kontroleur opnemen, die hem daarbij behulpzaam noest zijn en mij op mijne reis naar Nanga Badauw zoude vergezellen, om mij de noodige inlichtingen te geven omtrent de landstreek, het volk en het verbeteren der bestaande wegen, die daar nog zeer primitief zijn. De Kontroleur, de heer Bakker, was den vorigen dag juist uitgegaan op een tocht in zijn distrikt, doch wij kwamen hem den volgenden morgen met zijn kleine stoombarkas tegen. Even werd gestopt, om hem aan boord en zijn stoombarkas op sleeptouw te nemen, en de reis werd weder voortgezet. Of hij op dit reisje gerekend had, hetgeen zeker een dag of tien zoude duren, werd natuurlijk niet gevraagd. Dat doet men in Iadië zoo niet; men wordt geroepen en men zorgt maar altijd gereed te ziju; wij weten niet beter, of dit behoort zoo.

Men komt uit den Kapoeas door middel van de rivier Tawang, die een uur of vijf stoomens lang is, in de meren, waaronder men moet verstaan uitgebreide waterplassen, die in elkander loopen en genoemd worden naar de soengeis (kleine rivieren), welke er doorloopen en die bij zeer lagen waterstand zichtbaar zijn. De grootste zijn Danau Blidah (Danau beteekent meer), Danau Tehenang, Danau Sintoran, Danau Soembei, Danau Loewar, Danau Seriang en Danau Tongit; deze vormen te zamen een kolossaal bekken, dat eene verbazende hoeveelheid water kan bevatten en de plaatsen langs den Kapoeas gewoonlijk voor bandjers beschermt. Een groot gedeelte namelijk van het regenwater, dat in het gebergte valt, komt in deze meren te recht; is de waterstand van den Boven-Kapoeas hooger dan die in de meren, dan stroomt het door den Tawang derwaarts, en het omgekeerde heeft plaats, wanneer de waterstand in de meren hooger is. Overstroomingen, bepaalde bandjers, komen dus in de aan de hoofdrivier gelegen plaatsen niet dikwijls voor.

Het eigenaardige dezer meren is, dat zij grootendeels een verbazend uitgestrekt bosch vormen van struikgewas en kolossaal hooge boomen; toch bedraagt de diepte van het water bij gewonen waterstand op veel plaatsen 13 en bijna nergens minder dan 2 vadem. In den drogen tijd loopen de meren somtijds zoogenaamd droog, dat wil zeggen, dat men dan duidelijk kan onderscheiden de soengeis, die er doorloopen. Vooral was dit het geval in 1877 , toen men er uren ver doorheen kon wandelen. 
De omwonende Dajaks hadden van die gelegenheid gebruik gemaakt, om hier en daar de bosschen in brand te steken, louter uit plezier of baldadigheid, zoodat men thans op sommige plaatsen door uitgestrekte doode bosschen vaart, hetgeen een treurig gezicht oplevert en doet deriken aan bosschen bij een Nederlandschen watersnood in den winter. Bij diezelfde gelegenheid zijgn echter ook veel boomen van zelf dood gegaan, want ofschoon de hier groeiende boomen en struiken geheel van dezelfde soort zijn, als die op het droge en tegen de hellingen der bergen groeien, zijn zij zoo gewend, steeds in het water te staan, dat zij bij een paar weken droogte terstond sterven. Hetzelfde zoude waarschijnlijk plaats hebben met hunne soort. genooten, die gewoon zijn op drogen grond te groeien, wanneer zij gedurende eenige maanden een vadem of tien water om zich heen hadden; voorzeker eene opmerkenswaardig gevolg der gewoonte, zelfs in de natuur.

De meren zijn overvloedig voorzien van visschen, alle van eetbare soorten; vele er van behooren zelfs tot de zeer fijne soorten. Bij de hierboven beschreven droogte van 1877 hadden zij zich langzamerhand verzameld in de verschillende soengeis; deze waren dan ook zoo opgevuld met visch, dat men letterlijk met de sampan tusschen de spartelende visschen heenvoer, en zij bij hoopen in de sampans sprongen, zoodat men die van tijd tot tijd moest leeg scheppen, om voort te kunnen gaan. Een sampan is toch een zeer kleine prauw, slechts een sterk uitgeholde booınstam, zoodat men, wanneer men er mede vaart, bijna gelijk ligt met het water.

De mij vergezellende Kontroleur, die mij dit mededeelde, was toen reeds geplaatst in den Boven-Kapoeas. Hij heeft destijds zelfs een paar malen met een sampan door de soengeis gevaren en eens eenige uren door de meren geloopen. Dit moet echter een zeer vermoeiende tocht geweest zijn, want behalve de groote hoeveelheid steenen, boomtakken, wortels en omgevallen stammen, waar men door heen moest, had de bovenste grondlaag, die uit leemachtige klei schijnt te bestaan, zich als het ware in grootere en kleinere blazen opgeheven, zoodat het geheel het aanzien had, alsof er duizenden en duizenden van leem vervaardigde potten met bolvormigen bodem, zooals hier zooveel gebruikt worden, naast elkander te drogen gezet waren. Wanneer men den voet op die blazen zette, braken zij natuurlijk, en zakte men somtijds een heel eind in de diepte weg. Hij beschreef 
mij dien marsch als een van de vermoeiendste, dien hij in zijn leven gemaakt had, hetgeen nog al iets zegt voor een kontroleur uit de binnenlanden, die hier een zeer moeilijken en vermoeienden werkkring heeft. $\mathrm{Zij}$ zijn toch de werkelijke pionniers der beschaving, en er wordt heel wat van hunne moreele en fyzieke krachten gevergd.

Behalve aan visch ziju de meren ook rijk aan krokodillen en watervogels; van de laatste zag ik er den boerong wali, die de grootte hẹft van een patrijs met prachtige blauwe, roode en gele veeren en met een langen rooden snavel, ook den hierboven reeds genoemden bangan. Ofschoon ik er van deze slechts eenige zag, moet er volgens mededeeling van den Kontroleur B. toch eene groote menigte in de meren gevonden worden; zịj bouwen bij voorkeur hunne nesten in de struiken boven het water. Is toevallig in den tijd, dat zij eieren hebben, het water wat laag, dan gaan de Dajaks met kleine sampans eieren zoeken en komen dan dikwijls na verloop van een dag met hun sampan vol terug; deze eieren worden rauw, gekookt en gebakken door de bevolking als eene groote lekkernij bij de rijst gegeten.

In de meren liggen ook eenige eilandjes, die somtijds zeer hoog zi.jn. Het voornaamste is Poeloe Madjang, waar wij een station hebben; dat wil zeggen, er ligt daar een afgekeurde gouvernementstoomer, de Bennet, bij wijze van stationschip, gekommandeerd door een djoeragan, welke rang zoo wat gelijk staat met onderofficier bij onze marine. De goederen, bestemd voor onzen post te Nanga Badauw, worden daarheen gebracht en overgenomen en dan met sampans vervoerd naar Pangkalan Pesaja en verder over land naar Nanga Badauw. Dicht bij Poeloe Madjang, een weinig ten zuidwesten, heeft het gebergte drie schoone toppen, den Goenong Lempai, den Goenong Singkadjang en den Goenong Sliegier, die een prachtig gezicht opleveren. Ook wij lieten bij Poeloe Madjang het anker vallen, en terwijl de Bennet de medegebrachte goederen overnam, werd voor mij een hidar (een groote overdekte sloep) in gereedheid gebracht, want ik wilde nog dienzelfden middag door naar Pangkalan Pesaja, ten einde den volgenden morgen in de vroegte den weg over land naar Nanga Badauw te kunnen afleggen. Een uur na aankomst ging ik met mijn adjudant en den mij vergezellenden Kontroleur in de bidar, en nu begon de tocht door de eigenlijke bosschen; wij werden gesleept door 
de kleine stoombarkas, die aan den Kontroleur in gebruik gegeven is voor zijne dienstreizen, en die wij onderweg op sleeptouw genomen hadden.

Wij stoomden ruim twee en een half uur door de bosschen van den Danau Seriang en langs de rivier Seriang, die ook door het woud loopt en wijd overstroomde oevers heeft, en kwamen toen aan Kwala Pesaja. Hoe men den weg daarheen vindt, is mij onbegrijpelijk; men moet dien bepaald kennen, want men ziet niets anders dan boomen, struiken en water. Op het kompas varen is onmogelijk, daar het eigenlijke vaarwater zulke geweldige en vreemde kronkelingen makt, dat men dikwijls een kwartier lang stoumt in de tegenovergestelde richting van die, waar men eigenlijk heen moet. Een bepaald aangewezen route bestaat er niet, omdat men die eenvoudig wijzigt naar den hongeren of lageren waterstand en de meerdere of mindere grootte van het vaartuig. Omstreeks vier uur des middags kwamen wij te Kwala Pesaja aan; verder kon ons de bidar met stoombarkas niet brengen, zoodat wij overgingen in een kleine sampan, want nu gingen wij de Soengei Pesaja in. Hadden wij tot nog toe door open bosch gevaren, nu voeren wij in het dichte, op sommige plaatsen ondoordringbare woud.

De Soengei Pesaja is niet breeder dan van twee tot vijf meters en hier en daar bij lagen waterstand zeer ondiep. Van daar dat zulke soengeis dan ook alleen bevaarbaar zijn door kleine sampans, die nauwelijks één voet diepgang hebben; dikwijls vaart men onder de takken door, die in het water hangen, maar behalve die takken en ondiepten zijn er nog veel grooter hindernissen. Door den sterken stroom, vooral na gevallen regen, wordt de grond om de wortels der aan den oever staande boomen los gewoeld; de boomen beginnen daardoor aan beide zijden naar de rivier over te hellen, totdat zij eindelijk niet meer kunnen blijven staan en dus in of dwars over de rivier vallen. Van roeien is dan ook geen sprake, doch in den regel zitten er twoe of drie man in de sampan methouten pagaaien, om te scheppen, een voor en een of twee achter, of omgekeerd.

Sedert onze vestiging te Nanga Badauw, nu een jaar geleden, moet de communicatie natuurlijk zoo goed mogelijk opengehouden worden en de boomen zcoveel mogelijk worden weggeruimd, het. geen echter geen gemakkelijke taak is. Er zijn toch boomen bij, die 60 à 70 voet lang zijn en meer dan één meter middellijn 
hebben; hun hout is veelal als ịzer zoo hard, zoodat het dan ook dikwijls onmogelijk is, ze alle weg te ruimen. Voor een klein geruchtje bij dergelijke hindernissen zijn trouwens de in-

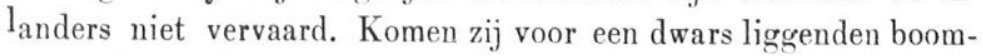
stam, die niet meer dan een decimeter boven het water uitsteekt, dan varen zij er met een aanloopje op aan, zoodat de sampan met een ruk een eind over den boomstam heen schiet. Als de wind springen zij dan in het water, lichten de schuit van achteren op, duwen haar tot over de helft van den stam en laten haar dan weer te water glijden; deze kunstbewerking ken ik bij ondervinding. Steken de boomstammen echte te hoog boven het water, zoodat dit kunstje niet kan worden uitgevoerd, dan stappen de passagiers uit en loopen om den boom heen; intusschen wordt de sampan door de bemanning over den boom gedragen en aan den anderen kant weder in het water gezet. Kan dit niet, ondat het terrein an beide oevers te moerassig is, ook daar weten zij raad voor; zij varen dan tot tegen den boom en plaatsen de passagiers met hun bagaadje daarop; dan scheppen zij de sampan vol water, totdat die zinkt, duwen haar onder den boom door en scheppen ze aan den anderen kant leeg; de passagiers stappen er weder met hunne bagaadje in, en de reis wordt voortgezet, alsof er niets gebeu:d was. Een en ander geeft echter altijd een oponthoud van een minuut of tien.

Hoe hooger de waterstand is, des te grooter gedeelte van het bosch staat op belangrijke diepte onder water. Men behoeft dan niet steeds de menigvuldige kronkelingen der soengei te volgen, maar snijdt gedeelten af, door hier en daar dwars door te steken; zij noemen dit pintaas, waarschijnlijk eene verbastering van het Maleische woord pinto (deur of doorgang.) Het was altijd eeu groote pret, wanneer men zulk een bruikbare pintaas ontdekte; de inlander, die vóór op de plecht zat te scheppen, gaf dit ten minste steeds met groote luidruchtigheid te kennen aan zijne kameradeu, die aan het achtergedeelte van de sampan zaten. Toen wij namelijk vier dagen later denzelfden weg weder terugvoeren, was het water wat gestegen, en waren dus eenige pintas bruikbaar.

Ik zal niet licht den indruk vergeten, die het varen op de Soengei Pesaja op mij maakte; het was ruim vier uur, toen wij er in gingen, dus de tijd, waarop hier in de bosschen de natuur zich begint voor te bereiden tot de nachtrust. Wij voeren met 
ons klein en smal schuitje, waarin juist plaats genoeg was voor ons drieën, de drie scheppers en een enkel stuk bagaadje, onder kolossaal hooge en zware boomen en dikwijls door hunne takken heen, waarlangs lianen als reusachtige slangen tot hoog in de lucht om en tusschen de boomen op de meest grillige wijze voortslingerden, ronder en dikker dan een mansarm. Alles was dood stil om ons heen; geen geluid werd gehoord dan alleen het scheppen onzer matrozen, die het langzaam en op de maat deden. Telkens als zij ophielden, om een oogenblik te rusten en weer op adem te komen, was het, alsof wij op geheimzinnige wijze door het water dreven, steeds dieper en dieper het donkere bosch in, want meer en meer begon de duisternis te vallen. Op sommige plaatsen, waar de boomen heel dicht bij elkander stonden, was het reeds geheel donker. Nergens was eenig leven te bespeuren, en onwillekeurig stemde dit alles ook ons tot stilte; men gevoelt zich zoo klein in zulk een grootsche natuur.

Geheel anders was dit schouwspel, toen wij eenige dagen later terugkeerden. Het was toen negen uur in den morgen; de opkomende zon verlichtte alles even vroolijk en helder en schoot hare stralen rechts en links door het geboomte, hetgeen dikwijls het meest prachtige kleureffect daar teweegbracht. Hier en daar, waar de zon nog niet of niet genoegzaam was doorgedrongen, dropen de dauwdroppels over de bladeren, die als zoovele diamanten in de zon schitterden, terwijl onderscheidene vogels zich in de boomen bewogen en bij onze nadering onder luid gekrijsch wegvlogen, of in de verte het gezang van andere vogels en het geschreeuw der apen luid weerkaatste.

Omstreeks half zeven kwamen wij te Pangkalan Pesaja aan; het was dus toen reeds geheel duister. Pangkalan Pesaja is een Dajaksch huis, gelegen aan het eind van de Soengei Pesaja en dient tot tusschenstation tusscinen Poeloe Madjang en Nanga Badauw. Het is bezet door een korporaal met tien fuseliers; de goederen worden van de Bennet tot hier per sampan gebracht, in het huis opgeslagen en achtereenvolgens door de bevolking en eenige dwangarbeiders over land naar Nanga Badauw getransporteerd. Mijne komst was geheel onverwacht, maar in een ougenblik had de korporaal met zijne soldaten en al hun hebben en houden het gebouw verlaten en zich opgeschoten in een kleine loods, welke daarnaast stond, het huis aan ons overlatende, waarin uu alleen nog maar een aantal kisten en vaatjes met 
vivres lag; onze bagaadje werd daarbij gevoegd, en wịj installeerden ons zoo goed mogelijk.

Onmiddellijk gingen de bedienden aan het koken, want op zulke tochtjes reist men steeds met kookgereedschap en het noodige voor den inwendigen mensch. Een groote kist werd gepromoveerd tot tafel, een ieder zocht zich een kistje uit tot zitplaats, en tegen acht uur zaten wij netjes bij het licht van twee aan den zolder hangende bollantaarms te soupeeren. Mijn adjudant had voor het menu gezorgd: een zeer goede groentesoep, zalm met worteltjes en aardappelen, boerenkool met aardappelen en worst, een goede flesch wijn en voor dessert een pisang; het was dus best uit te houden. $\mathrm{Na}$ het soupé werd mijn bultzak gespreid en mijn klamboe gespaunen in het hokje, dat afgeschoten was als verblijf voor den korporaalko!nmandant; het wemelt hier toch van muskieten. $\mathrm{Op}$ de baleh baleh der soldaten werd hetzelfde gedaan voor de heeren van mijn gevoly, dat bị onze aankomst met een officier vermeerderd was, die van Nanga Badauw, waarheen ik intusschen bericht van mijn komst had gezonden, door den kommandant was afgezonden, om mij te complimenteeren en mijne bevelen te vragen. Reeds spoedig zochten wij ons leger op, en weldra sliepen wij den slaap der onschuld.

Den volgenden morgen gingen wij om zes uur op marsch naar Nanga Badauw, dat zoo wat drie uur verwijderd is. De weg daarheen is lang niet gemakkelijk, en toch is het de eenige bruikbare; het is een smal voetpad, dat door de wildernis loopt, telkens over heuvels, waarvan sommige zeer steil zijn, en dan weder door uitgebreide moerassen, waardoor men een soort van knuppelweg gemaakt heeft. Dit wil zeggen twee of drie boomtakken van een mansarm dikte liggen naast elkaar, hier en daar met rottan verbonden; men heeft er dan ook groot nut van een langen, aangepunten stok, waarvan men zich bij het begin van den marsch voorziet. Over de ravijnen, smalle moerassen en riviertjes ligt alleen een enkele boomstam, meestal van ijzerhout, omdat dit zoo lang duurt, maar dat bij regen of des morgens vroeg, wanneer de dauw nog niet is opgedroogd, zeer glad is. $\mathrm{Ik}$ kan niet ontkennen, dat ik enkele min aangename oogenblikken heb doorgebracht, wanneer ik op zulk een gladden boom midden boven een ravijn of een suel bruisend bergstroompje stond. Aan eenige had men

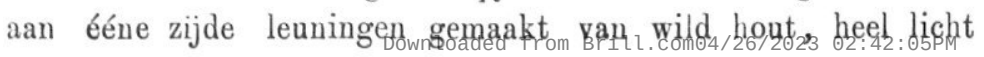


en met een rottan er aan vastgebonden, zoodat zij, wanneer de nood aan den man kwam, toch niet veel steun zouden geven; de gedachte evenwel, dat men, al is het dan ook maar met de toppen der vingers, ergens op kan steunen, wanneer men het evenwicht denkt te verliezen, draagt reeds veel bij tot het bewaren van de kalmte en het zelfvertrouwen. Het moeielijke is hoofdzakelijk gelegen in het ongewone en dus in de ongeoefendheid, om over die boomstammen te loopen. Enkele Europeesche soldaten, die ik als bedekking bij mij had, en die daar reeds eenige maanden waren en dus dikwijls dien weg gemakt hadden, liepen er met het geweer over den schouder over met een gemak, alsof zij hun leven lang niets anders gedaan hadden. In deze streken gebeurt het wel eens, dat men enkele troepjes van de naburige stammen ontmoet, die op een sneltochtje uit zijn; wij konden ze ook aantreffen, en ofschoon het wel niet waarschijnlijk was, zoude het toch kunnen gebeuren, dat deze of gene de verleiding niet kon weerstaan, voor de verandering ook eens een kop van een witten toewan mede naar huis te brengen in plaats van altijd die hunner bruine bloedverwanten. Daarom vond ik het voorzichtiger, een viertal soldaten als bedekking mede te nemen. Men ziet, dat zulk een Dajaksche weg nog niet precies een heerbaan genoemd kan worden.

Omstreeks negen uur kwamen wij te Nanga Badauw, waar ik mijn jaarlijksche inspectie moest houden, en dat gelegen is in het distrikt der Batang Loepar Dajaks. Nanga Badauw is een vierkanten redoute met twee cirkelvormige bastions over één der diagonalen. $\mathrm{Z}_{\mathrm{ij}}$ is geheel gebouwd van zoogenaamd wild hout, dat wil zeggen, hout, dat zoo maar in het bosch gekapt wordt en alleen van de schors wordt ontdaan. Heel sterk behoeft zulk een vesting hier ook niet te zijn, want geschut bezitten de Dajaks niet, behalve enkele kleine lilla's bij de hoofden, doch die nooit worden medegenomen, wanneer zij te velde trekken. Binnen de palissadeering is een officiersblok met doorgaande galerij, waarin ieder officier eene kamer heeft en de kommandant bovendien nog een voor bureau; verder zijn er twee kazernes voor de soldaten, een wachthuis, een ziekenzaal en een vivresmagazijn, waarin voor acht maanden proviand opgeborgen kan worden. Het is slechts een tijdelijke post, om in deze streken het koppensuellen tegen te gaan.

Bij de verschillende Dajaksche stammen, die het binnen- 
land van Borneo bewonen, bestaat nog altijd een groote zucht tot koppensnellen, dat is met den klewang het hoofd eens vijands van den romp te slaan. Vele onderlinge veten moeten zelfs volgens hun adat door koppensnellen uitgemaakt worden, en bij de meeste stammen bestaat nog de gewoonte, dat een jongen geen meisje ten huwelijk mag vragen, wanneer hij niet één of meer zelf gesnelde koppen kan vertoonen. Door onze regeering wordt dit natuurlijk ten sterkste tegengegaan; strenge straffen en geldboeten zijn er op gesteld, terwijl aan de bevolking telkens en bij iedere gelegenheid het verkeerde en onmenschelijke van dit gebruik onder het oog gebracht wordt. Daar echter de binnenlanden door ons niet bezet zijn, behalve in enkele posten, kan dit onmogelijk altijd verhinderd worden. Ieder jaar, wanneer de padioogst binnen is, gaat men zoo hier en daar op sueltochten uit, en dat niet alleen om onderlinge twisten te beslechten, maar wel degelıjk ook oin te rooven. Nu gebeurde dit bijna ieder jaar onder de Batang Loepars, en voordat wij er met onze patrouilles tusschenbeide konden komen, waren de daders reeds over de grenzen gevlucht naar Serawak, waar de heer Brooke Radja is. Door de civiele en militaire autoriteiten werd daarom overeengekomen, op de grens van het Serawaksche tijdelijk een post op te richten, en werd daarvoor gekozen het punt Nanga Badauw; de noodige voorstellen werden aan het legerbestuur gedaan en door de regeering goedgekeurd. Tegen het einde van Februari 1880 begon men met den bouw der versterking, die in Mei zoover voltooid was, dat de geheele bezetting er in kon. De maatregel heeft tot dusver gunstig gewerkt, want na de oprichting van Nanga Badauw wordt er nog wel eens een enkele maal gesneld, wanneer men de kaus schoon ziet, maar georganiseerde sneltochten hebben sedert niet meer plaats gehad.

Op weg naar Nanga Badauw kwamen wij de eerste Dajaks tegen, een twintigtal mannen en vrouwen, die door het hoofd van een der huizen op last van den Kontroleur waren uitgezonden, om onze bagaadje over te brengen, waarmede zij dan ook 's middags tegen één uur ordelijk en wel aankwamen. De Dajaks zijn over het algemeen groote, flink gebouwde mannen; ook de vrouwen zijn goed gebouwd, maar meestal veel kleiner dan de mannen. Groote weelde in humne kleeding hebben zij niet. Evenals de Alfoeren dragen de mannen alleen een smalle strook goed, 
die, eens om de heupen geslagen, tusscheu de beenen doorgehaald en van achteren vastgemaakt wordt. Bij de vrouwen en meisjes is die strook wat breeder, reikt zij tot even boven de knie en wordt alleen eens om de heupen geslagen. De kinderen van beider kunne loopen tot hun negende of tiende jaar geheel naakt. Zeer enkele mannen, en dan nog alleen de voornaamste, dragen een baadje, wanneer zij in tegenwoordigheid van Europeanen moeten komen; ook bij de vrouwen begint dit meer en meer navolging te vinden. Het is dan echter zeer onvolkomen gemaakt en van ruwe stof, dikwijls maar van goelit kajoe (boomschors), maar het bedekt dan toch wat.

De mannen hechten veel aan versieringen; vele namelijk dragen om den hals kettingen van die kleine, veel gekleurde kraaltjes, waar bij ons de kinderen mede spelen en ringetjes van maken. Eenige van die aangeregen kettingjes worden tot één ketting vereenigd, waar hier en daar grootere kralen, blauwe en roode pitjes of boomzaden tusschen geplaatst worden, ook wel zeeschelpen, die in Zeeland veel gevonden worden en daar kinkhoorntjes genoemd worden, zooals ik ze dan verder ook maar noemen zal. De kettingen gaan om den hals en hangen met kwastjes van dezelfde kralen, pitten en kinkhoorntjes op de borst. $\mathrm{Om}$ de bovenarmen dragen zij gladde koperen ringen van gewoon dik koperdraad, ook wel breede banden van een soort van porselein of gebakken klei; deze laatste worden er meestal zoodanig omgelegd, dat zij er niet meer afgenomen kunnen worden en dan ook mede worden genomen in het graf. Om de polsen dragen zij armbanden van kraaltjes, zooals hierboven bij de kettingen beschreven is, en bovendien aaneensluitende gladde koperen ringen, soms tot aan den elleboog. Sommigen dragen die kopereu ringen ook aan de beenen, van den voet tot over den enkel; eenigen zelfs tot aan de knie. Enkelen zag $\mathrm{ik}$, die bovendien nog een rij gewone koperen schelletjes aan de enkels gebonden hadden, zoodat men hen met elken stap kon hooren; dit is bijzonder voornaam. Een andere Dajak had een soort van baadje aan, waarvan de onderkant eveneens met eeri rand van die schelletjes omzoomd was, hetgeen natuurlijk nog voornamer was.

In hunne ooren hebben zij in de oorlel een wijd gat, waarin een groote gladde ring hangt van koper, ijzer of lood; sommigen hebben daaraan nog een touwtje vastgebonden van een centimeter of vijf, waaraan een stuk zeeschelp hangt of de
Downloaded from trill.como $4 / 26 / 2023$ 
slagtand van een wild zwijn. Langs de geheele oorschelp hebben zij gaten, "aarin weder kleinere ringen hangen; anderen hebben den geheelen rand van de oorschelp versierd met een aaneensluitende rij kinkhoorntjes. Op onze terugreis was onder de goederendragers een jongen van een jaar of twaalf, die zich voor deze plechtige gelegenheid al heel mooi gemaakt had. Hij had een ruw afgewerkt baadje aan, dat een gedeelte van zijn bovenlijf bedekte; in zijne ooren droeg hij groote koperen ringen, waaraan een touwtje met een stuk zeeschelp. en daaraan weder een touwtje van gelijke lengte, waaraan een halve cent hing van het jaar 1857. Deze jongen was dus erg op zijn Zondags, hetgeen hem echter niet belette, een gepakt handkoffertje van een 20 kilo zwaarte te dragen.

Deze oorversieringen zijn in zoover van belang, omdat men daaraan de verschillende stammen herkent. De Kajan Dajaks bijv., die ik op mijn verdere reis te Sibauw ontmoette, hebben maar één groot gat in de oorlel en een boven in de oorschelp, waarin zij alleen groote gladde ringen dragen; wanneer zij die er niet in hebben, gebruiken zij ze als sigarenkokers en bewaren er hunne half opgerookte sigaretten in. De vrouw van den Raden, zoo heet het hoofd van Sibauw, had ook een paar half opgerookte sigaren in hare oorgaten gestoken. Een teeken van voornaamheid is, wanneer zij in plaats van die ringen, slagtanden van wilde zwijnen in de gaten steken; een groot bewijs van voornaamheid is echter de lengte der oorlel, hoe langer die is, des te voornamer het hoofd. Te Sibauw kwam een Dajak bij ons aan boord, wiens oorlellen bijna op de schouders hingen; men kon door het gat met gemak twee handen steken. Hij had zijn zoontje bij zich, een jongen van een jaar of zeven, die in dit opzicht ook reeds tot hoofd werd opgevoed, want dit kind droeg in ieder oor zeven zware looden ringen, en de gaten waren dan ook reeds zoo groot, dat men er met gemak den vinger door kon steken.

De vrouwen doen daarentegen veel minder aan versieringen dan de mannen. Bij de Batang Loepars droegen enkele een eenvoudig eflen kettingje van zilver of koper om den hals, de meeste echter niets; slechts weinige hadden groote ringen in de ooren, waardoor de oorlel ook wel wat was uitgescheurd, doch lang niet zooals bij de Kajan Dajaks. Om armen en beenen dragen zij echter dezelfde koperen ringen, en ook op dezelfde wijze

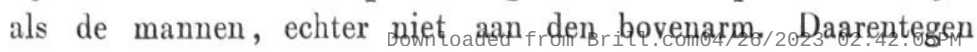


wordt het stukje doek, dat zij om de heupen dragen, zeer versierd, namelijk van boven tot onder met rijen van eenvoudige koperen vingerringen, verschillende kleine pitjes van boomen bloemzaden, gladde gordijnringen en kinkhoorntjes; de onderste rijen worden op het doek vastgehecht, de bovenste doen zij echter een voor een aan, zoodat een Dajaksche schoone, al heeft zij geen meter goed aan haar lijf, toch veel tijd noodig heeft voor haar toilet. Van haar haar maken zij weinig werk; het fladdert haar wild om het gezicht en van achteren wordt het saamgedraaid tot een groote wrong. Bij de mannen dragen sommige het haar kort, evenals de meeste Maleiers, anderen echter lang; het hangt dan recht langs hals en schouders. Overmaat van zindelijkheid kennen zij niet, zoodat dan ook velen aan huidziekte lijden als gevolg hunner onreinheid.

Zijn dus de Dajaks, zoowel mannen als vrouwen, in hun dagelijksch costuum hoogst eenvoudig gekleed, geheel anders is het, als zij op feesten gaan; dan hangen zij alles, wat zij maar hebben aan het lijf, hoe meer des te voornamer. De vrouwen van het troepje, dat wij tegenkwamen, vooral de jonge, waren in het eerst zeer schuw en verborgen zich ter zijde van het voetpad tusschen de struiken, niet zoo zeer, omdat zijj bang zijn voor de Europeanen, maar er kwamen daar op eens zooveel toewans tegelijk aan. Toen zij echter bemerkten, dat wij beleefd en vriendelijk tegen haar waren, was die schuwheid spoedig verdwenen, en mochten wij zelfs van nabij hare versierselen bekijken en met de hand aanraken.

Zijn de Dajaks schamel in hunne kleeding, even eenvoudig zijn zij in hunne levenswijze; zij wonen met eenige gezinnen te zamen in een groot huis, waarop ik straks nader terug zal komen. Hun hoofdvoedsel, bịna hum eenig voedsel, is rijst, die zij zelf verbouwen; verder is hun middel van bestaan hoofdzakelijk ruilhandel met metalen en boschproducten, voornamelijk rottan, dammar, gutta pertja, was en boomvet. Een eigen munt bestaat bij hen niet, overal echter is onze munt gangbaar; ook ruilen zij rijst en boschproducten in tegen stofgoud of stukjes goud en ander metaal; het koper, dat bij hen veel in gebruik is, krijgen zij hoofdzakelijk uit Serawak. Hun godsdienst is weinig ontwikkeld en slechts eene vermenging van het Hindoeisme en het Mahomedanisme, maar van ieder een heel klein beetje.

Zooals ik hierboven reeds met een enkel woord zeide, be- 
staan de Dajaks uit verschillende stammen. In deze streek zịn de voornaamste de Batang Loepars, de Kajans, de Kantauws en de Belahans, welke laatste stam weder verdeeld is in Belahan Boekit en Belahan Ajer Dajaks. Een zeer wilde stam zijn de Poenans; deze leven ineest in de boomen en zijn nog geheel natuurmenschen, zij hebben zelfs geen gemeenschap met de andere Dajaksche stammen. Toch drijven zij ook wel handel, doch op eene zeer primitieve wijze; enkele plaatsen op de grens van hun stamgebied zijn hiervoor aangewezen. Wanneer toch de naburige Dajaks met de Poenans handel willen drijven, brengen zij humne waren, meestal bestaande in rijst, tabak, doeken, wapens, metalen en kramerijen naar die plaats en geven dan een bepaald teeken; daarop komen de Poenans, die het dichtst bij wonen, bekijken het te koop aangebodene en leggen daarnaast zooveel van hunne boschproducten, metalen of dierenhuiden, als zij er voor geven willen. Zij verwijderen zich dan weder, en op een gegeven teeken komen de verkoopers terug; kunnen die zich vereenigen met den aangeboden prijs, dan nemen zij dien mede, geven een teeken en de Poenans komen het op die wijze door hen gekochte halen. Vinden de verkoopers echter, dat er te weinig is nedergelegd, dan nemen zij van hunne waren weder een gedeelte af en geven opnieuw het teeken, om te komen kijken. Dikwijls gebeurt het dan, dat de koopers ook weder wat van het hunne medenemen, en zoo moet er somtijds heel wat heen en weer geloopen of gevaren worden, voordat de koop gesloten is.

In het werk van Professor Veth over de Wester-Afdeeling van Borneo (D. I, bl. 167) wordt vermeld, dat volgens een der vroegere reizigers, die deze streek bezocht hebben, de wervelkolom bij de Poenans zoo lang is, en het onderste gedeelte zoo op zich zelf is uitgegroeid, dat er werkelijk een staartje gevormd wordt. Ware dit zoo, dan zoude er een groote schrede voorwaarts gedaan zijn tot bewijs der theorie van Darwin, doch hier is daarvan thans, voorzoover ik heb kunnen nagaan, niets bekend. Wel is waar vertoonen zij zich hoogst zelden, doch de Kontroleur Bakker is eens in hume streek geweest, ik geloof bij gelegenheid van een rechtsgeding, en hij verklaarde mij, geen enkel persoon met een staart gezien te hebben. Het zijn echter ruwe boschmenschen met uiterst weinig ontwikkeling, die voor een groot gedeelte alleen van boomwortels, bladeren en vruchten leven.

Eigenlijke kampongs bestaan bij de Dajaks niet of beter 
gezegd een Dajaksche kampong bestaat uit één groot huis, verdeeld in een aantal kamertjes, waarvan ieder gezin er een bewoont. Zulk een kamertje heet pinto, waarschijnlijk naar de deur. Een huis bevat dus zóóveel pinto's, als gezinnen; er zijn er zelfs, die 150 pinto's hebben. In sommige van die huizen, die alle een voor- en achtergalerij hebben, zijn de kamertjes werkelijk afgesloten, behalve dat de binnenwanden meestal bestaan uit wildhouten stokken, die op afstanden van een paar centimeters bevestigd worden, zoodat zulk een kamertje veel heeft van een groot traliehok, waarin in plaats van dieren menschen wonen. In andere huizen is bovendien nog een doorloop door het midden van al de kamertjes, zoodat men ongehinderd van het eene in het andere kan komen. Alleen de woning van het hoofd van het huis, is wat grooter dan de andere kamertjes en van de overige afgescheiden. Ieder gezin leeft geheel op zich zelf, alsof ieder in een afzonderlijk huis woonde, doch zij staan gezamenlijk onder toezicht van het hoofd van het huis, in den regel de oudste of de aanzienlijkste.

Dit hoofdschap is een baantje, waarvan men niet veel anders dan last heeft. Het hoofd beslecht namelijk de kleine geschillen, die tusschen de families onderling voorvallen, en is aan de Regeering en de Maleische Vorsten verantwoordelijk, dat er steeds orde en rust heerscht Traktement onder welken vorm ook krijgt hị daarvoor echter niet; ook doen de bewoners van het huis niets voor hem bij wijze van heerendienst, zooals dit op Java en Sumatra plaats heeft. Bij geschillen tusschen de bewoners van verschi!lende huizen zin het weder de hoofden, die deze trachten te vereffenen; bij ernstige gevallen echter komen zịj bij den Kontroleur of bij de Vorsten. Bij de jaarlijksche volkstelling wordt door de Regeering het aantal bewnonde pinto's als grondslag aangenomen en gerekend, dat iedere pinto gemiddeld vijf bewoners heeft, hetgeen 7oowat uitkomt.

Op ongeveer een half uur afstand van Nanga Badauw, kwamen wij aan het eerste huis en daarna nog aan twee; dit waren echter geen groote huizen, maar van 10 tot 20 pinto's. In een er van werd aan een oud moedertje gevraagd, hoeveel personen groot en klein er wel in het huis woonden. Dit wist het oudje niet; zij wist alleen, hoeveel pinto's er waren, en hoeveel personen er in iedere pinto woonden, maar om nu op eens te zeggen, hoeveel er in het geheel waren, was haar veel te geleerd: zij zou het echter uitrekenen. Daartoe legde zij op den 
grond zooveel strootjes (inlandsche sigaretten) op eenigen afstand van elkander als er zich pinto's in het huis bevonden, en daaronder zooveel strootjes, als er bewoners in iedere pinto waren, en toen ging zij aan het tellen. Het duurde wel wat lang, maar zij kwam er toch en kreeg toen voor belooning een Manilla-sigaar, die zij dankbaar aannaun.

De huizen zijn geheel van wild hout gemakt; als het heel mooi is, zijn de stijlen zoo wat vierkant bekapt. Versieringen van snijwerk, zooals men die in andere deelen van den Archipel bijna overal en dikwijls zeer fraai aantreft, vindt men hier niet. Deze woningen zijn hoog boven den grond gebouwd, hetgeen een tweeledig doel heeft; vooreerst omdat onder de huizen de bewaarplaats is van het weinige vee, dat zij houden, wat kippen en eenden, soms een enkele geit of varken, maar vooral geschiedt zulks, om beveiligd te zijn tegen lanssteken, wanneer zij des nachts op den vloer liggen te slapen. De vloeren bestaan namelijk uit latten van wild hout, sointijds ook wel uit dikke rottans, die op afstanden van een paar centimeters op de vloerbalken met gespleten rottan vastgebonden worden. Om in het huis te komen, is er dus een trap noodig, die eenvoudig bestaat uit een in de lengte door midden gespleten boomstam, welke schuin tegen de doorloopende voorgalerij wordt opgezet met de bolle zijde vaar boven, en waarin dan eenige treden gekapt worden. Als het heel mooi is, wordt er een leuning aangebonden, doch dikwijls is dit niet het geval. Is het huis zeer lang, dan worden er meer dergelijke trappen aangebracht.

De buitenomwaudingen en ook de dakbedekking bestaan uit zoogenaamde kajoe goelit, dat woordelijk vertaald houtleer beteekent; het is de schors van verschillende boomen, zooals de mang, pengawan, merentang en tehalang, wordt gesneden in stukken van circa én vierkanten meter en is een halven duim dik. Het is zeer sterk en heeft een rood-brume kleur; voor dakbedekking is het echter minder geschikt, omdat het, aan regen en zonneschijn blootgesteld, aan de hoeken omkrult, zoodat men er een raam van dwars over elkander liggende stokken overheen moet leggen. Sommige huizen zijn dau ook gedekt met alang alang, dat veel beter en netter is; zulks kost echter veel meer arbeid en dit is iets, dat niet in den smaak valt van de Dajaks. Door langdurig kloppen wordt de kajoe goelit zeer zacht, ik zag een stuk van meer dan een vierkanten meter groot; dat de dikte en zachtheid had van bruin ffumeel, In dien vorm 
wordt het dan ook als kleedingstuk gebezigd; voor het bouwen der huizen wordt het natuurlijk niet geklopt en is dan zoo hard als gewoon hout.

De hoofdstijlen, gebinten en vloerbalken der huizen zijn in den regel van ijzerhout; dit is eigenlijk het kajoe siblian, dat overal op Borneo in groote hoeveelheid gevonden wordt, en waaraan om zijne verbazende sterkte en duurzaamheid de naam van ijzerhout gegeven is, eene benaming reeds zoo algemeen bekend, dat de Maleiers die in humne taal letterlijk weergeven door kajoe bissi (kajoe is hout, bissi ijzer). Het is verbazend hard en dus niet gemakkelijk te bewerken, maar het is ongeloofelijk duurzaam; een goed met de noodige zorg gebouwd huis van ijzerhout kan zeker wel honderd jaren staan. Wanneer het gezaagd of bekapt eenigen tijd aan de lucht is blootgesteld, wordt het zwart als ebbenhout en is dan uitstekend voor vloeren. De trappen en vloeren mijner woning te Pontianak zijn er van gemaakt en, wat de voor- en achtergalerij betreft, te mooi, om met matten te beleggen; zij worden gemakkelijk schoon gehouden met natte doeken. Dit is een der vele prachtige houtsoorten, waaraan geheel Borneo zoo rijk is.

Een andere sterke en zeer duurzame soort is het kajoe temboesoe. Terwijl ik te Sintang was, werd op het achtergedeelte van het erf om de Assistent-Residentswoning diep gegraven, omdat daar een nieuw huis gebouwd moest worden. Het bleek, dat daar vrneger een kerkhof geweest was, en er werden onderscheidene potjes, kleine gendies en kommetjes opgegraven, die men aan lijken in het graf medegeeft; ook werd er gevondeu een doodkist, die bij onderzoek bleek te zijn van kajoe temboesoe en waarvan de planken een centimeter of vier dik waren. Van het lijk, dat er eenmaal in gelegen had, was niet het minste spoor meer te ontdekken, maar het hout was nog zoo gaaf, alsof de kist pas gemaakt was. Toen men er met de bijl in hakte, gaf het denzelfden klank en had op de snede hetzelfde aanzien, als hout, dat nog geen jaar geleden geveld was; toch had die kist zeker meer dan vijftig jaar een voet of zes diep in den grond gezeten. Wordt dus het kajoe sibiian ijzerhout genoemd, dan kan men gerust het kajoe temboesoe koperhout noemen, te meer daar het een licht gele kleur heeft evenals palmhout.

$\mathrm{Na}$ deze kleine uitweiding keeren wij nog voor een oogenblik naar de woningen der Dajaks terug. Veel comfort wordt er niet gevonden: een paar van rottan gevlochten manden, 
waarin de dagelijksche levensbeboeften geborgen worden, een groote steenen pot, die als vuurhaard dient, een paar aarden pannen, om in te koken, een martevaan met drinkwater en eenige klapperdoppen; verder in een hoek een stuk mat op den vloer, waarop de geheele familie bij elkander slaapt, en hier en daar aan den wand een klewang, lans en schild, de wapens, die zij gebruiken, als zij ten ooorlg trekken of op een sneltocht uitgaan; ziedaar al hun huisraad. Bij de hoofden der huizen vindt men ook niet veel meer. Alleen bij de groote en rijke hoofden is het wat beter gesteld; zoo had de Raden van Sibauw, dien wij een bezoek brachten, en die bekend staat als een aanzienlijke rịkaard, drie stoelen, één wipstoel en twee gewone; voor de meerdere heeren, die bij mij waren, werden kleine kistjes opgescharreld, die hun tot zitplaatsen dienden. De Raden met zijne vrouw, zijn gevolg en al de andere Dajaks - want langzamerhand kwam de geheele mannelijke bevolking van het huis met een groote partij kinderen in de kamer - zaten alle op den grond. Een tafel was er niet, maar in ons midden stond een kist, die daarvoor dienst deed, bij deze plechtige gelegenheid overdekt met een stuk gee? laken; geel is de vorstelịke kleur. Nadat wij wat hadden zitten praten - bijna alle hoofden spreken vrij goed Maleisch werd zelfs aan ieder onzer een glas limonade-stroop met water voorgezet; hier was dus de beschaving al eenigszins doorgedrongen. Ook hingen er aan den wand een paar kleine spiegels en eenige schilderijtjes, voorstellende schepen en poppetjes in de onmogelijkste vormen en zoo bont mogelijk gekleurd.

Een zeker teeken van grooten rijkdom en aanzien is het bezit van veel groote gongs en tampajans; de eerste zijn gelijk aan de groote gong van het gamelanspel. Er hingen er wel een stuk of twaalf op een rij en daarnaast waren zes tampajans, die netjes naar de grootte gerangschikt stonden en zorgvuldig met doeken gedekt waren. Die tampajans zijn groote Chineesche martevanen (steenen potten), zooals men overal in den Archipel vindt en die eene gemiddelde waarde hebben van $f 25$ het stuk. Een veel grooter waarde hebben zij echter bij de Dajaks, hoewel ik het er voor houd, dat zij ook van Chineeschen oorsprong zijn. Mon betaalt er somtijds tot duizende dollars voor; de Panembahan van Sintang (een vorstentitel iets minder dan Sultan) heeft er onderanderen een in zijn bezit, die op ruim vijfduizend dollars geschat wordt en steeds overdekt is met een 
geel zijden doek. Waaraan de Dajaks deze potten onderkennen, en welke bijzondere merkteekenen zij hebben, weet ik niet, want zij zijn daar zeer geheim mede, maar zeker is het, dat die bestaan. Eenige jaren geleden had een slimme Chinees van Sintang zulk een Dajaksche tampajan weten machtig te worden en die naar China gezonden, waar zij zoo juist mogelijk werd nagemaakt, hetgeen de Chineezen zoo goed kennen. Daarna werden alle kunstmiddelen aangewend, om den pot zoo oud mogelijk te doen schijnen, en die vervolgens hier en daar bij de aanzienlijkste Dajaks te koop aangeboden; doch deze hadden het onmiddellijk in den neus en boden er niet meer voor dan vijf tot tien dollars, dat dan ook de werkelijke waarde was. De Baba kwam dus heel slecht van zijne speculatie af. Voorzoover ik uit de gesprekken daarover kon opmaken en daaromtrent rechts en links opving, houd ik het er voor dat de groote waarde hoofdzakelijk afhangt van de grootte, den ouderdom en van de personen of families, aan wie de pot heeft toebehoord. Ik denk, dat er van die zeer oude en dure tampajans op eene of andere wijze een register wordt aangehouden. Zij worden in den regel nergens toe gebruikt en staan eenvoudig leeg; alleen bij groote feesten komen zij wel eens voor den dag en worden dan voor de gasten gevuld met een soort van sterken drank, die uit rijst, palmwijn (saguweer) en nog enkele andere vruchten en ingredienten gemaakt wordt, en waarvan dan groote hoeveelheden gedronken worden.

Hoe eenvoudig toch de Dajaks in hun dagelijksch leven zijn, bij feesten kunnen zij zich verbazend te buiten gaan; de hoofdschotels bestaan dan uit rijst, djagong, gebraden varkens en kippen en uit dezen drank. In het laatste huis, het dichtst bij Nanga Badauw werd bij onze nadering muziek gemaakt. De Kontroleur zeide mij, dat dit een goed teeken was, hetgeen men gaarne zag. Volgens den adat namelijk mag in een huis geen muziek gemaakt worden, wanneer men nog in den rouwtijd is over afgestorvenen, of wanneer er zaken hangende zijn met de Vorsten of het Gouvernement wegens overtredingen, ook wanneer er onderling met andere huizen of stammen nog iets af te rekenen valt. Als men dus muziek in een huis hoort, dan is dit een zeker teeken, dat men daar een geheel schooue rekening heeft. De muziek-instrumenten der Dajaks hestaan uit enkele stukken van den gamelan, waarbij de kleine gong en eene schel snerpende soort van klarinet de voornaamste zijn. 
De rechtspraak bij de Dajaks is in handen van de hoofden der huizen, de hoofden der stammen en van den Vorst, aan wiens gebied de stam of een gedeelte er van door ons is toegevoegd. Enkele overtredingen, zooals die tegen het Gouvernement en sommige zware misdrijven, waarop de doodstraf staat, worden door den Land- of Residentieraad berecht. Men is thans bezig, een voorschrift te maken omtrent de geheele invoering van onze Nederlandsch.Indische rechtspleging. De straffen, door de inlandsche hoofden opgelegd, bestaan in den regel in boeten, waarbij als maatstaf dient de meerdere of mindere rijkdoin van den gestrafte, voorts in gevangenis en verbanning uit het gebied van den stam. Ook worden sommige zaken wel eens beslecht met een sneltocht; doch dit zijn zaken, die zij onder elkander afdoen, en waarin de hoofden niet, of ten minste niet officieel, gekend worden, omdat het koppensuellen streng door de Re geering verboden is. Kunnen partijen het onderling niet eens worden, of wel hebben er kleine overtredingen van de bevelen van het Gouvernement plaats, dan wordt de hulp van den Kontroleur ingeroepen.

Ofschoon het overspel bij de Dajaks zwaar gestraft wordt en dikwijls bloedwraak eischt, zoodat het dan ook, voorzoover bij onze ambtenaren bekend is, slechts zelden voorkomt, geeft men echter alle vrijheid in den omgang tusschen ongehuwde mannen en vrouwen. Wordt echter het meisje zwanger, dan is dit eene groote schande; hoogst zelden gebeurt het, dat zij later een huwelijk doet, tenzij zij zeer mooi of rijk en aanzienlijk is, en dus, hetgeen wij eene goede partij noemen. $Z_{i j}$ is daarom wel geen verstooteling en men heeft zelfs betrekkeliik niet veel minder achting voor haar, maar zij wordt niet ten huwelijk gevraagd, tenzij door den vader van het kind, die daartoe dikwijls wel genegen is, maar waartegen zich in den regel zijne ouders verzetten, en wanneer de ouders er tegen zijn, mag het niet. Door het hoofd van het huis, of wanneer de beide personen tot twee verschillende huizen behooren, door de hoofden dier beide huizen, wordt dan een boete bepaald, die de man aan het meisje moet geven, waarbij alweder als maatstaf dient de meerdere of mindere rijkilom van den man in verband met het aanzien, dat de familie van het meisje geniet. Weigert de man of zijn familie, de brete te betalen, dan drong vroeger het meisje met eenige van hare vriendinnen en familie-leden het huis van den man binnen en roofde alles, wat zij machtig kon 
worden; dit zich zelf recht verschaffen is echter door ons streng verboden, omdat het in strijd is met iedere eenigszins geordende maatschappij; zij moeten daarom nu de hulp van den Kontroleur inroepen.

Onmiddellijk na onze komst te Nanga Badauw kwam een der hoofden den Kontroleur mededeelen, dat eenige dagen geleden een geval zich had voorgedaan, als hier beschreven werd; dat den man een boete was opgelegd, die zijne familie weigerde te betalen; dat het meisje daarna bij haar minnaar was gaan rooven; en dat hij de partijen opgeroepen had, om hen bij den Kon. troleur te brengen, doch dat zij weigerden op te komen. Dadeliik werd toen een der Dajaks, die het hoofd vergezelden, teruggezonden met de boodschap, dat de partijen onmiddellijk in de benting moesten komen, en om an den last de noodige kracht bij te zetten, hem de sabel met schede en draagband van den oppasser van den Kontroleur medegegeven. Tegen zulk een dwangbevel is geen Dajak bestand, en na verloop van een paar uur waren beide partijen dan ook opgekomen; de Kontroleur hield een kort voorloopig onderzoek en bepaalde, dat hij den volgenden dag rechtsdag zoude houden. De terechtzittingen zijn publiek; den volgenden morgen omstreeks tien uur waren dan ook in en voor de voorgalerij van het officiersblok binnen de benting verzameld de beide partijen, de hoofden en nog een menigte manneu en vrouwen, wel een honderdtal.

De zaak werd toen besproken; beide partijen waren geheel in confessie; de hoofden hadden een boete aan den man opgelegd, die zịne fanilie weigerde te betalen. Daarom had het meisje zich zelve recht verschaft, was in de woning van haar minnaar gedrongen en had zich in plaats van de boete het een en ander van hem toegeeigend. De man wilde het meisje wel huwen, maar zijne ouders waren daartegen, hetgeen door deze, die ook ter terechtzitting aanwezig waren, bevestigd werd. De Kontroleur sprak daarop met de hoofden, deze overlegden onderling een poos, en deze of gene van het publiek sprak ook al eens een woord mede. Eindelijk werd er door een der hoofden een stuk van een boomtak in het midden der vergadering geworpen, waar. aan op zekere hoogte een wit porseleinen plaatje bevestigd was; dit plaatje geeft de grootte der boete aan, dat wil zeggen: hoe hooger het bevestigd is, des te grooter de boete. De Kontro. leur nam het stuk hout op, bekeek het met aandacht, sprak nog een paar woorden met de hoofden en keurde toen hun 
voorstel goed. De man werd veroordeeld, aan het meisje te betalen tien rijksdaalders, terwịl zij de geroofde voorwerpen aan den eigenaar terug moest geven, en omdat zij tegen het verbod der Kompanjie zich zelve recht had verschaft, bovendien nog eene boete van vijf rijksdaalders aan den lande betalen moest. De uitspraak werd a!gemeen goedgevonden en de boete onmiddellijk betaald; de vergadering ging welgemoed uiteen, daarna werd aan de hoofden wat tabak uitgedeeld. Dit is iets, waar de Dzjaks verbazend op verzot zijn; men kan hun geen grooter genoegen doen, dan hun wat tabak te schenken. Bij alle samenkomsten van de hoofden met onze ambtenaren of officieren wordt hun bij het scheiden dan ook een handvol tabak vereerd; ook zijn zij zeer gevoelig voor een glaasje jenever of brandewijn.

$\mathrm{Na}$ vier dagen verblijf te Nanga Badauw keerden wij naar Pangkalan Pesaja terug. Reeds bij het aanbreken van den dag verzamelden zich eenige Dajaksche mannen en vrouwen in de benting, die besteld waren, om onze bagaadje te dragen. Zij gingen des morgens om zes uur gezamenlijk met ons op marsch en in weerwil der vrachten, die zij droegen, konden zij ons toch zeer goed bijhouden; velen liepen ons zelfs vooruit.

De Dajaks dragen alleen op den rug; zij hebben daartoe een langwerpige van rottan gevlochten mand, die aan de voorzijde geheel open is; er ziju twee draagbanden aan bevestigd, die over de schouders en onder de armen doorgaan, en dan nog een band, die langs het voorhoofd gaat. De mannen dragen op die wijze met het meeste gemak uren ver vrachten van 40 kilo; de vrouwen de helft, maar daar loopen zij dan ook als kieviten mede over den weg. De jongere vrouwen liepen te stoeien en te schertsen en hadden een pret als Hollandsche boerinnetjes, die naar de markt gaan; toch had ieder een gepakt koffertje van 15 à 20 kilo zwaarte op den rug. Dat wịj, de groote heeren, dikwijls het onderwerp van die pret waren wegens de weinig handige wijze, waarop wij over de boomstammen liepen, hetgeen in hun oog toch zoo verbazend eenvoudig is, daarvan ben ik zeker. Het pikelloon tusschen Na:ga Badauw en Pangkalan Pesaja, een afstand van circa drie uur, wordt berekend op twee centen per kilo en steeds onmiddellijk na ankomst uitbetaald; de vrouwen binden het ontvangen geld meestal in de punt van haar schortje, de mannen stoppen het binnen in hun ooren.

Met twee of meer personen tegelijk of op de schouders dragen 
de Dajaks geen vrachten, zij dragen alleen op den rug; de zware of groote voorwerpen van kazerneering, zooals lange tafels, ijzeren bedkribben en loopplanken, bestemd voor de bezetting van Nanga Badauw, werden eerst uit elkander geslagen, dan overgebracht en op laatstgenoemde plaats weer in elkander gezet. Toch ging het overbrengen nog maar zeer langzaam. Zij dragen liever een zak rijst van 40 kilo op den rug, dan een plank van 5 pond op den schouder; telkens als zij een kwartier geloopen hadden, smeten zij die tegen den grond en bleven dan een half uur rusten; zij waren dan wel zesmaal zoolang onder weg als anders.

Bij gelegenheid dat er eens veel zieken onder de dwangarbeiders waren, veroorzaakte dit groote moeielijkheid bij het overbrengen der zieken, die geévacueerd moesten worden en daartoe gelegd werden in een brancard, gedragen door twee man. $Z_{i j}$ vonden er niets in, den man op de schouders te nemen, of zich een stoel op den rug te laten binden, waarop de patient gezeten was, maar om met hun tweeën ees brancard te dragen, weigerden zij halsstarrig, omdat zij zeker wisten, zooals zij zeiden, dat zij den zieke onderweg eenige malen zouden laten vallen. Kleine en lichte zieken, zooals inlanders en vrouwen, konden zij op die wijze vervoeren, maar met Europeesche militairen, die zooveel zwaarder zijn, was dit onmogelijk; deze moesten dus wel op de gewone wijze door dwangarbeiders gedragen worden. Kisten met goederen, die te groot of te zwaar zijn voor één man, slaan zij eenvoudig open, verdeelen den inhoud in eenmans vrachten en gaan er mede op marsch.

Men kan hun daarin gerust hun gang laten gaan, want nimmer zal er zelfs het kleinste voorwerp aan ontbreken; daarvoor zijn zij te eerlijk. Kisten jenever van 15 vierkante flesschen, die te zwaar zijn voor vrouwen en kinderen om te dragen, maken zij open, verdeelen de flesschen onder elkander en brengen die, waar ze wezen moeten. Nimmer ontbreekt er een ffesch aan, en toch zijn zij hartstochtelijke lief hebbers vau sterken drank, en weten zij heel goed, dat zij gemakkelijk eenige flesschen zouden kunnen verantwoorden, als onderweg gebroken, zonderdat dit gecontroleerd zou kunnen worden. Ook het stelen onderling komt in den eigenlijken zin van het woord bij hen zeer zelden voor, behalve natuurlijk de groote sueltochten, dat tevens rooftochten zijn. $Z_{i j}$ drijven zelfs hun eerlijkheidsgevoel 
zoover, dat, wanneer iemand in het bosch een mooien vruchtboom vindt of een boom, waarin groote bijennesten zitten, en hij geeft daar een soort van eigendomsteeken aan als eerste vinder, dit steeds geëerbiedigd wordt; geen ander zal er aan raken. Zij vragen om alles en kunuen alles gebruiken, maar zich ongevraagd iets toeeigenen, al is het ook nog zoo gering, dat doen zij niet. Bij het bezoek der huizen vroeg zelfs eene oude vrouw aan mijn adjudant, zijn unifornijas uit te trekken en die present te geven aan een klein kind, dat zij op den arm droeg. Weigert men hun een verzoek, daarom blịven zij toch even goede vrienden en komen er dan ook niet weer op terug.

Over het geheel maakten de Dajaks op mij den indruk, goedaardige, onbezorgde, vroolijke natuurkinderen te zijn. Toch zijn zij nog halve wilden, wanneer hunne hartstochten eenmaal in beweging gebracht zijn, en echte kannibalen in den oorlog. Dezelfde Batang Loepars, waarmede wij zoo vriendschappelijk omgingen, hadden slechts een jaar of drie geleden een roofen sneltocht gemaakt in het gebied van de Kajans. Zij overvielen daarbij een huis dicht bij Boenoet en vermoordden niet alleen alles, wat er in was: zeventig mannen, vrouwen en kinderen, maar sneden zelfs de zwangere vrouwen den buik open, om de nog niet geboren kinderen met den klewang het hoofd af te slaan.

Toen wij te Pangkalan Pesaja aankwamen, was het daar een verbazende drukte, want buiten ons vertrokken nog de officier van gezondheid, een der officieren en eenige mindere militairen van Nanga Badauw, die daar een jaar verblịf gehouden hadden en daarom werden afgelost, en voor wie ik de vervangers had medegebracht; ook moesten eenige zieke militairen naar Sintang geévacueerd worden. Niettegenstaande allen als in een mierennest dooreenkrioelden, begon de Kontroleur met zijn oppasser dadelijk met de meeste gerustheid het pikelloon uit te betalen, overtuigd als hij was, dat geen der dragers of draagsters voor de tweede maal loon zoude komen vragen of grooter zwaarte zou opgeven, dan de vracht werkelijk was. Zij zijn namelijk bij het afwegen der vrachten tegenwoordig, en aan ieder hunner wordit gezegd, hoe zwaar zijne vracht is.

Reeds vroeg in den morgen hadden wij onze bedienden vooruit gezonden naar Pangkalan Pesaja, om het een en ander in gereedheid te brengen voor onze rijsttafel, die wij later in de bidar moesten nuttigen. Bij onze aankomst waren zij dan ook druk 
bezig, op kleine vuurtjes in de open lucht het noodige te koken en te braden. Toen alle personen en goederen omstreeks negen uur in de verschillende sampans geladen waren, werd het sein tot vertrekken gegeven; spoedig werden dus alle potten en pannen van het vuur genomen en in onze sampan geplaatst. Alles was gelukkig voldoende gereed, behalve onze aardappelen; deze waren nog maar half gebakken, maar dat zouden wij later wel in orde trachten te brengen op de stoombarkas, die onze bidar weder moest sleepen, doch er deed zich een veel gunstiger gelegenheid voor.

Omstreeks twaalf uur kwamen wij aan de Kwala Pesaja, waar een huis staat, dat vroeger als tusschenstation diende tusschen Poeloe Madjang en Pangkalan, doch in den laatsten tijd verlaten was. Wij bespeurden daarin echter eenige beweging en hoorden menschenstemmen, zoodat wij er met onze sampan even voeren. Wij vonden er drie mannen en eene vrouw, die tot daar geloopen waren en naar Pangkalan Pesaja moesten, doch hiervoor hadden zij een sampan noodig, die zij natuurlijk niet hadden, en nu bleven zij maar geduldig wachten, totdat er eens een ledige sampan voorbij zoude komen, die hen medenam. Op het midden van den vloer stond de vuurpot, waarin nog een klein beetje vuur smeulde; de Kontroleur verzocht de vrouw, het vuur wat aan te blazen en onze aardappelen verder af te bakken. Als belooning daarvoor kregen zij de vergunning, met een juist voorbijkomende sampan naar Pangkalan Pesaja te gaan; zoo ziet men, op reis komt alles terecht! Een eind verderop vonden wij onze bidar met de stoombarkas, zooals wij die bij het heengaan daar achter gelaten hadden. $W_{i j}$ stapten onmiddellijk over, en eenige oogenblikken later zaten wij met een keurigen eetlust, ieder met een bordje rijst op den schoot, waarbij wij ons de door de Dajaksche vrouw gebakken aardappeltjes ook best lieten smaken.

Intusschen sleepte ons de barkas naar Poeloe Madjang terug, en waren wij des middags om twee uur weder op de Boni; deze had den geheelen dag met gebankte vuren gelegen en was dus binnen een half uur klaar om te stoomen. Wij verlieten nu de meren en kwamen door den Tawang weder in den Kapoeas. Wij gingen toen naar Salimbauw en Boenoet, waar de Assistent-Resident met de Vorsten politieke zaken had af te handelen. Den volgenden dag kwamen wij in den voormiddag voor eerstgenoemde plaats, doch het regende zoo ver- 
schrikkelijk, dat ik geen lust had, aan den wal te gaan, omdat ik er toch niets zoude kunnen zien. De Assistent Resident ging dus met den Kontroleur alleen aan land, en een paar uur later kwam hij terug, medebrengende den Sultan met zị̣n rijksbestierder of eersten minister; Zijn Hoogheid had verzocht, zijne opwachting bij mij te mogen komen maken. Hij was gekleed in een lang paars zijden baadje met groene bloemen, een wit onderkleed en een witten tulband; de eerste minister in een zwart, tamelijk vuil baadje van merinos of zoo iets, ook met e€n wit onderkleed en witten tulband. Beide kwamen mij voor, tamelijk ontwikkelde mannen te zijn; wij hielden een praatje over de eigenaardigheden van het volk, het land en de te velde staande gewassen. $\mathrm{Na}$ een half uur vertrok hij, en gingen wij onder stoom naar Boenoet. $\mathrm{W}_{\mathrm{ij}}$ hadden iutusschen van de gelegenneid gebruik gemaakt, om onzen kolenvoorraad aan te vullen, en den volgenden dag te Boenoet deden wij zulks weder.

Zooals ik vroeger reeds heb medegedeeld, vindt men bijna over geheel Borneo steenkolen, doch in deze streken zijn er zeer veel. Zij worden door of voor rekening van de Vorsten gedolven, en aangezien de meeste dezer Vorsten bij onze Regeering in het krijt staan wegens genoten voorschotten, mogen zij op afkorting hunner rekeningen aan ons kolen leveren tegen betaling, wanneer stoomers in hunne nabijheid komen. De prijs is thans nog door ons bepaald op $f 1$ de pikol, om de exploitatie zooveel mogelijk aan te moedigen, maar zal spoedig gesteld worden op 90 en 75 cents, want de kolen zijn nog van zeer inferieure kwaliteit. Het graven geschiedt natuurlijk door de bevolking, die daartoe zeer primitieve, dikwijls zelfs in het geheel geene gereedschappen gebruikt, zoodat het voor hen zeer moeielijk is, diep te graven. $\mathrm{Nu}$ is het van algemeene bekendheid, dat bijna overal de bovenste kolenlaag de slechtste is wegens de vermenging met aarde en andere vreemde bestanddeelen. Het product, dat zij leveren, kan dan ook niet anders dan slecht wezen, want zoodra zij op een voet of zes diepte komen, wordt het hun te moeielijk, dus gaan zij liever een eind verder op, om daar weder de bovenste laag weg te nemen, hetgeen veel gemakkelijker is. Het duidelijk bewijs hiervan is, dat de kolen van Salimbauw beter zijn dan die van Boenoet; op eerstgenoemde plaats is men toch reeds veel langer met het kolengraven bezig, zoodat men daar genoodzaakt wordt, al 
wat dieper te gaan. Vooral de kolen van Boenoet zijn nog zeer slecht; zij geven zeer veel asch door de vermenging met aarde, zeer veel rook en veel vonken, maar weinig vuur. Het kostte de uiterste moeite, stoom genoeg te houden om met volle kracht te kunnen doorvaren, en toch werd er per wacht tweemaal zooveel gebruikt als van gewone kolen. Daarbij schijnt er nogal ijzererts in te zijn, waardoor zich in den vuurhaard groote klompen vormen, en de roosters aangedaan worden, die later moeielijk schoon te maken zijn; bovendien worden daardoor de roosters telkens voor een groot gedeelte bedekt, zoodat het de grootste inspanning kost, om de vuren behoorlijk te onderhouden.

Den volgenden dag omstreeks twaalf uur kwamen wij voor Boenoet, doch het bleek dat de Vorst niet te huis was, maar zich bevond te Sibauw, nog één dag stoomens hooger de rivier op. Hier hadden wij echter een eigenaardige ontmoeting; nauwelijks was het anker gevallen, of wij zagen een sampan met groote snelheid naar ons toekomen, waarin twee Chineezen gezeten waren, terwijl een verschrikkelijk bebloede Chinees onder een klein afdakje van atap in bewusteloozen toestand lag. Men vertelde ons het volgende: de gewonde was met zijn bandong (een groote prauw) van beneden gekomen, om te Boenoet handel te drijven; daartoe moest hij echter de plaats voorbij, waarvan ik hierboven gesproken heb, die een jaar of drie geleden door de Batang Loepar Dajaks uitgemoord is. Hierdoor hebben de inlanders altijd nog eene zekere vrees, als zij dicht bij die plaats komen, en daarom had de Chinees, om de gemeente schrik aan te jagen, en waarschijnlijk ook om aan zijn eigen bangheid tegemoet te komen, eene kleine koperen lilla, die hij aan boord had, geladen en afgeschoten. Dit scheen echter een oud geschenrd ding te zijn, ten minste bij het eerste schot sprong het stuk uit elkander en verwondde hem op onderscheidene plaatsen, zoodat hij bewusteloos nederviel. Het gebeurde dicht bij Boenoet; men had hem dus onmiddellijk naar die plaats overgebracht, en nu kwamen zij vragen, of er bij ons ook een dokter aan boord was, die hulp konde verleenen; dit was gelukkig het geval.

Wel is waar is er op de gouvernement-stoomers geen dokter, maar wij hadden den officier van gezondheid tweede klasse aan boord, die van Nanga Badauw was afgelost en bij het garnizoen te Sintang geplaatst was. Deze had reeds met schitterende

4e Volgr. V. 
oogen naar het verhaal staan luisteren en van tijd tot tijd eens een begeerigen blik in de sampan geworpen, want dit was een kolfje naar zijn hand; de dokters noemen dat mooie gevallen. In een oogenblik had hij zijne instrumenten voor den dag gehaald, terwijl groote stukken linnen en hoopen pluksel uit de medicijnkist van het schip te voorschijn werden gebracht. Toen werd met de meest mogelijke zorg de patient uit de sampan gelicht en zoo voorzichtig mogelijk op het achterdek neergelegd. Een der officieren bood zich aan, bij den dokter te blijven, ten einde hem bij het verbinden te assisteeren, terwijl wij naar den wal gingen, om Boenoet te zien.

Het is een groote kampong, hoofdzakelijk bewoond door Chineezen en Maleiers en geheel boven het water gebouwd, zoodat niet alleen de huizen, maar ook de wegen van hout zijn. $\mathrm{W}_{\text {ij }}$ hadden daar echter nog een zeer voorname zaak te verrichten, daar de voorraad versch vleesch aan boord begon op te raken; daarom hadden wij op verzoek van den gezagvoerder op ons genomen, te trachten aan den wal wat te krijgen. Wij kochten dus voor rekening van het schip bij een Chinees twee vette varkens, en aangezien er maar éen persoon was, die er koeien op na hie!d, namelijk de Vorst, kochten wij van het hof een jonge koe. Deze stond tusschen andere groote en kleine koeien in een groote kraal, ook al boven het water, en was niet gemakkelijk te pakken, doch de prinsen beijverden zich nog meer dan hunne ondergeschikten, het dier machtig te worden, want het verkoopen van eene koe was een buitenkansje, dat zoo niet iederen dag voorkomt. Eindelijk was men het rund zoover meester, dat de vier pooten bij elkander konden gebonden worden; toen werd het over een smal plankje den stal uitgedragen en onder de banken van onze sloep geschoven, waarin ook wij weder plaats namen. Het arme dier scheen het in die positie niet erg gemakkelijk te vinden, ten minste het maakte een spektakel, dat wij bijna met sloep en al naar den kelder gingen; een onzer pakte het daarom bij den staart, een ander zette het den voet op den neus. Dit scheen voldoende te zijn, om de koe te doen begrijpen, dat zij zich een weinig rustig moest houden; eeu oogenblik later kwamen wij dan ook behouden en wel met het dier aan boord.

Juist was de dokter met zijn gewonden patient gereed; hij had hem aan de rechterzijde uit het hoofd gehaald een stuk koper, vier duim lang, $2 \frac{1}{2}$ breed en $1 \frac{1}{2}$ dik, waaraan een aantal 
hersens en beensplinters gekleefd zat, en een tweede stuk, half zoo groot, uit zijn rechterbeen; bovendien had hij hem nog op vier andere plaatsen verbonden, waar hij ook wonden had. Gedurende de operatie was de Chinees niet bij kennis gekomen, en de dokter had die niet willen opwekken, om hem voor pijn te vrijwaren; hij was met zeer veel zorg en netjes verbonden, en zoo werd hij weder heel voorzichtig in de sampan gelegd. Zijne geleiders kregen een groote flesch karbol-water mede, om het verband nat te houden, en een flesch medicijnen, waarvan den patient om het uur een lepel moest gegeven worden. Toen werd het anker gelicht, en gingen wij weder onder stoom naar Sibauw, want de Assistent-Resident moest noodzakelijk, den Vorst ontmoeten. De dokter gaf ons niet veel hoop op het leven van den Chinees, en terugkomende hoorden wij dan ook, dat hij den volgenden morgen om drie uur overleden was.

Het landschap Boenoet schijnt nog al veel goud te bezitten; totnogtoe wordt het niet gegraven, maar hoofdzakelijk gevonden in de Boenoet, een groote zijrivier van den Kapoeas. Het wordt daarin meestal gevonden in den vorm van stofgoud, maar ook wel in stukken, en de Vorst van Boenoet heeft sedert een paar jaar een stuk goud in zijn bezit, zoo groot als een kleine manshand, dat door een inlander gevonden is. Een ieder mag goud zoeken, en het gevondene is het eigendom van den vinder; alleen grootere stukken mogen zij niet houden, maar deze moeten zij onmiddellijk bij den Vorst brengen, die ze hun voor een redelijk goeden prijs afkoopt. Er bestaat toch een volksgeloof, dat hij, die een stuk goud vindt en het in zijn bezit houdt, zwaar ziek wordt, en hoe grooter het stuk, des te zwaarder de ziekte. Het spreekt van zelf, dat dit volksgeloof zeer zorgvuldig onderhouden wordt; het toeval wilde, dat de vinder van het groote stuk, waarvan ik hierboven sprak, de koorts kreeg, toen hij het een paar dagen in zijn bezit had; dus haastte hij zich, om het bij den 'Vorst te laten brengen.

Den volgenden morgen kwamen wij te Sibauw, dat slechts uit één groot huis bestaat. Van ons bezoek aldaar bij het hoofd, die den titel van Raden heeft, heb ik vroeger reeds het een en ander medegedeeld. Er kwam hier een menigte hoofden van verschillende kleinere stammen aan boord, zoodat het daar een bont en druk gewoel was. Sommige kwamen met hunne oorlogsprauwen, lange en tamelijk breede vaartuigen, voor het grootste deel voorzien met een glad dek van gevlochten rottan; de 
groote kunnen van 50 tot 70 man bevatten, waarvan een gedeelte roeit. Ongeveer op het midden is eene kleine verhevenheid, waarop het hoofd staat, die van daar zijne bevelen geeft en het gevecht bestuurt.

De wapens der Dajaks zijn een lange lans, de klewang en een groot schild, dat veel overeenkomst heeft met de schilden der oude Germanen. Het bestaat uit twee lange rechthoeken van sterk, doch licht hout, die onder een zeer stompen hoek aan elkander bevestigd zijn; van boven en onder eindigt het in een driehoek. Aan den binnenkant is in het midden een houten handvat; van buiten is het versierd met allerlei geschilderde figuren en van boven tot onder in rijen op geliike afstanden bezet met kleire bosjes menschenhaar, ongeveer een palm lang. Men heeft wel eens beweerd, dat dit alles haar was van zelf gesnelde koppen, doch zulks is zeer overdreven; misschien is het wel eens het geval met een beroemden voorvechter, doch regel is het volstrekt niet. Men gebruikt er voor ziju eigen hoofdhaar of dat van vrouwen of kinderen, dat tot op eene zekere hoogte wordt afgeknipt. De klewang is een zeer sterk en geducht wapen in humne handen, zij zijn zoo scherp als scheermessen. De Dajaks dragen die altijd in een houten scheede met een gevlochten koord ow het lijf; aan den zijkant van die scheede is nog een kleinere aangebracht, waarin zij een mesje hebben, dat zij gebruiken evenals wij het zakmes. Sommige bezigen in den oorlog ook donderbussen en oude slechte vuursteengeweren, waarmede zij onhandig omgaan en zeer slecht schieten. Ook hebben zij nog een houten blaasroer, dat een paar meter lang is en waaruit zij pijltjes blazen, die naar gelang der omstandigheden, al dan niet vergiftigd zijn. $\mathrm{Zij}_{\mathrm{ij}}$ gebruiken die hoofdzakelijk op de jacht, om vogels en klein wild te dooden, maar wanneer zij er de kans schoon toe zien, schieten zij ze elkander ook wel in het lijf; tot op betrekkelijk groote afstanden treffen zij daar vrij zeker mede.

Wanneer de Dajaks ten strijde trekken, bedekken zij het lichaam zooveel mogelijk met een geitevel, dat zlj met het haar naar buiten dragen. Tusschen de voorpooten snijden zij een gat, waardoor zij het hoofd steken, zoodat een gedeelte op de schouders en den rug valt en het overige het voorlijf dekt; ter hoogte van den buik hebben zij daarop een ronde blikken plaat bevestigd. Sommigen zetten ook een muts op van geitevel, somtijds versierd met vederen van fazanten. De hoofden en aanvoer- 
ders gebruiken in plaats van geitevellen de huid van de tijgerkat, die hier half zoo groot is als een gewone tijger, en dragen in plaats van de blikken plaat groote platte schelpen.

Een geregelde wijze van oorlogvoeren hebben zij niet; zij trekken steeds tegen elkander op in dichte drommen, maar ten gevolge van hunne bewapening is het altijd een gevecht van man tegen man. Hunne voornaamste kracht bestaat in krijgslisten, want zij trachten steeds hun vijand te verschalken en te overvallen; dit bleek mij duidelijk uit een krijgsdans, die aan boord voor ons werd uitgevoerd. Heel veel bijzonders was die niet, verschrikkelijk veei zwaaien met klewang en schild, nu eens langzaam vooruitkruipende en dan weder groote sprongen makende, terwijl men telkens het lichaam snet suelheid omdraaide. Duidelijk werd hierin nagebootst het bekruipen van den vijand, het wantrouwen, om zich voort te bewegen, eu de zucht, om het lijf zooveel mogelijk te dekken.

Ook voerden zij voor ons uit den zoogenaamden apendans, waarin eene voorstelling gegeven wordt van het leven der apen in de natuur, hun samenwonen, op uitkijk staan, hunne voortdurende nieuwsgierigheid, het vruchten plukken, onderlinge vechtpartijen, hoe zij in een mierennest verdwaald raken, enz. Het is werkelijk grappig, en wat men het meest daarbij moest bewonderen, was de lenigheid der vertooners. Beide dansen werden begeleid door een zeer eentonige muziek, voortgebracht door eene primitieve soort van doedelzak. Dit instrument bestaat namelijk uit een groote, holle vrucht, een kalebas met krommen, spits toeloopenden hals; deze dient tot mondstuk, en de geringe verscheidenheid van tonen verkrijgt men door vier rietstokjes, welke tot een bundeltje gebonden in de kalebas bevestigd worden, terwịl deze hier en daar gaatjes heeft, die men met de vingertoppen kan sluiten.

$\mathrm{Na}$ een dag verblijf te Sibauw namen wij de terugreis weder aau, verzeld door den Vorst van Boenoet, die den titel heeft van Pangéran, een gezellige dikzak en een verbazende prater is. Bij gebrek aan plaatsruimte logeerde hij op zijn matje op het achterdek, maar at met ons aan tafel, en hoewel hij natuurlijk te huis gewoon is, met zijne vingers te eten, ging hij toch vrij handig met ons tafelgereedschap om.

Men zal bemerkt hebben, dat de Westerafdeeling van Borneo bestaat uit een menigte van grootere en kleinere rijken, die gere geerd worden door Sultans, Paneıbahans, Pangérans, enz. Men 


\section{2}

kan omtrent hen een vrij uitgebreide en juiste beschrijving lezen in het vroeger reeds aangehaalde werk van Professor Veth; zij zijn bijna alle van Maleische of Boegineesche afkomst. Met ieder dezer Vorsten hebben wij contracten van leenverband gesloten, en de meeste rijken worden geheel geregeerd door onzen invloed, die zich steeds uitbreidt. Er zijn echter zeer kleine staatjes onder; zoo brengt, ik meen, de Vorst van Piassa, wanneer hij zoo sterk mogelijk uitrukt, wel een leger op de been van 30 met piek en klewang gewapende strijdbare mannen. Voorts is hier de Heer van Koeboe, dien ik verleden jaar een bezoek bracht met den Resident op mijne reis naar Soekadana; de Heer was van onze komst verwittigd, en dus werden wij met statie ontvangen. Bij onze aankomst net de stoombarkas roerde het leger de trom; gedurende ons debarkeeren verwisselde het handig de trom met de piek en stond het, uitgedost in rood en geel, bij wijze van eerewacht aan de trap van het hoofdgebouw, waarin wij ontvangen werden; toen wij heengingen, metamorfozeerde het zich op eens in artillerie en schoot drie lilla's af, die op den grond lagen en van te voren geladen waren. Dit leger bestond uit één man, gewapend met een piek, en de Heer van Koeboe krijgt een traktement van $f 50$ 's maands.

Onze reis had reeds een paar dagen langer geduurd, dan waarop gerekend was; daar ik voor de aankomst der maandelijksche mail van Batavia weder op mijn standplaats moest wezen, en er dus niet veel tijd meer overbleef, deden wij op de terugreis geene plaatsen meer aan, behalve even Boenoet. Dit speet mij zeer, want ik had gaarne de schatten van den Vorst van Boenoet gezien, maar vooral had ik een tegenbezoek willen afleggen bij den Sultan van Salimbauw. Den 1sten April kwamen wij weder te Sintang, en den 5 den April was ik te huis.

Pontianak, 18 Mei 1881. 